\title{
Transtitial Woman: New representations of women in contemporary French
}

\author{
cinema
}

\section{Phil Powrie}

\section{Introduction}

A perceptible change has been occurring in French cinema. While at one end of the spectrum, the heroine remains as spectacular and spectacularized as ever, at the other end there are women on screen who seemingly escape spectacularity. An example of this polarization is the very different Joans in Luc Besson and Jacques Rivette's versions of Joan of Arc: a big-budget spectacular with a top-model who overacts (and over-reacts) and a grueling art film with an art-house actress whose overwhelming concern according to the many interviews she gave was to be "human", for which read to be an "ordinary" woman (Besson, The Messenger: The Story of Joan of Arc,1999; Rivette, Jeanne la Pucelle, 1994).

A political reason for this shift could be the now welcome number of women directors, who wish to demythologize woman-as-spectacle. And indeed the shift is perhaps most perceptible in films by women directors, such as Romance (Catherine Breillat, 1999). But, as the example of Rivette suggests, it is by no means confined to them. A second, more general social reason for the shift, would be the postmodern attraction to representations of the ordinary, renewing with the social cinema of the 1930s and the realist cinema of the 1970s; the aura of spectacle has become the ordinary of the everyday.

Whatever the reasons, I am here more concerned with the effect. These women are clearly a spectacle -- they are objects of the gaze -- but they are not spectacular or spectacularized in the "to-be-looked-at-ness" sense. The gaze constructed by these 
films no longer seems clearly voyeuristic, or caught in the sadistic/fetishizing binary. I used the term "ordinary" above; but the women in question are not so much “unspectacular" as "unspectacularized".

In what follows, I shall try to substantiate my perception of this shift, and then try to theorize it, one problem being, as the already too frequent quotations marks have no doubt suggested, semantic.

\section{New Representations}

The new representation is clearest in films with little-known actresses, for example the mother in Sandrine Veysset's Y aura-t-il de la neige à Noël? (1996). Dominique Reymond had worked principally in the theatre with Antoine Vitez, with a few walkon or small parts in seven films, followed by a more substantial part as Hélène in $L a$ naissance de l'amour (Philippe Garrel, 1993). Rosetta, on the other hand, was Émilie Dequenne's first role (Jean-Pierre and Luc Dardenne, 1999). Despite the difference in age between the actresses, the two films are similar in that the two women are presented as 'ordinary women', locked in a brutalizing environment, unglamourized either by costume (they both wear Wellington boots, for example), or by cinematographic style, which, with its muted colors, location-bound soundtrack, and paucity of music, has the documentary feel of Maurice Pialat's films of the 1970s. Although there are significant differences between the way the two women are framed by the camera - Reymond is usually in medium or medium-long shots, Dequenne in close-ups or medium shots with a very mobile camera, "dans l'espoir d'apercevoir son vrai visage", as one reviewer put it $^{1}$ - nevertheless, comments made about Rosetta apply to both. Reviewers talk of a sense of the daily grind percolating through Rosetta's activities in the film, which is "dur comme le quotidien". ${ }^{2}$ Much is made of 
the character's expressionlessness: “si le visage de Rosetta est beau, c'est parce qu'il ne dit rien". ${ }^{3}$ The same reviewer goes on to praise Rosetta's "sensationnelle absence", while another explains how she is "incessamment menacée de disparition [...]. Rosetta [...] refuse en définitive qu'on la cadre, et, si le personnage fascine, on est bien prêt de ne pas pouvoir l'encadrer"; for him, Rosetta is "un signe indéchiffrable". 4 The difference between indecipherability and enigma (fascination being predicated on both) lies in the unglamourized expressionlessness. It is not that the characters of these two films repel, far from it; it is that their attractiveness is not spectacularized allure. It is not surface suggesting penetrable depth into a fantasized body (as might be the case with the spectacularized femme fatale), but uneroticized depth. This is a problematic notion, because depth might suggest penetrability; or, to put it another way, depth is always susceptible to enigmatization. Nevertheless, in these instances, the body and its struggle in the real is the surface; as the filmmakers put it in interviews, when commenting on Dequenne's blushing, the young actress "exprime par son corps ce qu'elle éprouve". The characters in these two films are perhaps best characterized by their resistance (to despair, to alienating structures), even if the mother of Y aura-t-il de la neige à Noël?, melodramatically, almost gases herself and her seven children at the end of the film.

What of better-known actresses? In Le Septième ciel (Benoît Jacquot, 1997), Sandrine Kiberlain plays a sexually unfulfilled woman whose encounter with a mysterious hypnotist produces an orgasm. Although it was her first starring role, she had appeared in small roles in eighteen films, and had become increasingly visible in major supporting roles prior to Le Septième ciel $^{6}$ Unlike the two films discussed above, Le Septième ciel is not realist, since there is considerable ambiguity as to 
whether the hypnotist exists in the film's reality or in Mathilde's imagination. And unlike the other two films, Mathilde is in control, as Jeff Kline points out:

She rejects definitions of herself as a mere object ... rearrange(s) her space and her life, confront(s) her physician husband's medical authority, and challenge(s) his diagnosis of her by openly expressing her desire and forcing him to confront his own homosexuality. ${ }^{7}$

And yet, Kiberlain's performance is in line with the other two actresses. Jean-Michel Frodon comments on her "quotidienneté", ${ }^{8}$ and Kiberlain herself remarks on the same phenomenon, albeit in the context of films directed specifically by women: "Les femmes que (les réalisatrices) racontent et filment sont plus accessibles, plus familières, plus quotidiennes .... Les femmes sont moins magnifiées qu'avant"9 A good example of what she might mean is the working-class wife played by Valeria Bruni Tedeschi in Rien à faire (Marion Vernoux, 1999), who by her constant selfdisparagement and what is constructed as working-class attention to the cheapness and practicality of food (rather than its nutritional value, like the middle-class cadre she falls for) suggests the "ordinariness" discussed, although Bruni Tedeschi's performance is considerably more expressionist than Kiberlain's cold blankness.

As I pointed out above, however, films by men also seem to move in this direction. An interesting case is Erick Zonca's La vie rêvée des anges (1998), not least because its two heroines, although both young, are played by Élodie Bouchez, an actress with some twenty films before this one, including several significant roles in successful films, ${ }^{10}$ and, by contrast, Natacha Régnier, with only three minor films before this one. The contrast between the two performances is striking. Bouchez, despite her very naturalistic performance and her similarity to Rosetta in her daily struggle for survival, is a new version of the old ingénue (as stressed in Clubbed to 
death (Yolande Zauberman, 1996), where her character, Lola, befriends Saida, played by an ingénue of the 1980s, Béatrice Dalle). Régnier, on the other hand, corresponds more to the new unspectacularized woman. This is perhaps partly because she is less well-known than Bouchez, but arguably more through her performance. Whereas the Bouchez character, Isa, always busy, always interested in others, open-mouthed and irrepressibly optimistic, comes across as a single type, Régnier's tight-lipped anger is the only common feature which holds together a kaleidoscope of 'types', as one reviewer astutely pointed out: "successivement pocharde et sophistiquée, féminine, enfantine et androgyne" ${ }^{, 11}$ Her lack of spectacularity is epitomized by her suicide. This is merely glimpsed, like Bosch's Icarus, in the far distance, a fall noticed more through her companion's reaction shot, than through the fleeting image of the fall caught through a doorway.

The analysis of La vie rêvée des anges would suggest, returning to my first point, that the new representation of women works best with little-known actresses. And yet, I would argue that Sandrine Bonnaire's performance as Joan of Arc in Rivette's film exhibits the same features, which are all the more easy to identify when she is contrasted with Besson's Joan. The same issue of "ordinariness" combined with "quotidianness" surfaces in comments on Rivette's Joan, who is "inspirée et quotidienne", 12 "prosaïque ... terre à terre", ${ }^{13}$ as one reviewer put it, "même les batailles ont un air de vie quotidienne". ${ }^{14}$ Indeed, the word used most frequently by reviewers, the director and the star is "human", since, as all concerned agreed, his Joan was a demythologized Joan, stripped of ideological baggage accumulated over the $19^{\text {th }}$ century, as well as through the forty or so film versions of the myth, so that Frodon could say that Rivette's Joan "ne 'représente' rien. Elle existe, libre"15 Curiously, Besson's Joan is also demythologized, “dénuée de tout mystère, de toute 
mystique"; ${ }^{16}$ but, clearly, the demythologization has a different purpose, even if it is rather unkindly put by Libération's reviewer: “dépoussiérer la Pucelle illuminée en pop-star androgyne, icône MTV ou junkie martyre". ${ }^{17}$ Besson suggested, like Rivette, that he too wished to make Joan more human, ${ }^{18}$ but his Joan does not have the quotidianness of Rivette's, nor the ordinariness of the new representation of women; how could a heavily mediatized top-model for Versace, Calvin Klein, Dior and Chanel, whose face has appeared regularly on the covers of women's magazines since she was eleven years old, be anything other than extraordinary?

What then of Catherine Deneuve, whose face has also graced many a cover, and whose bust has adorned many a town hall, as Marianne? In Place Vendôme, Deneuve is both spectacle, as the film's star, and yet undermined as spectacle, since we see her act out the ravages of alcoholism, her usual composure gone, her hair and face in disarray (Nicole Garcia, 1998). One way of interpreting this performance is to agree with Ginette Vincendeau that the myth of Deneuve is so strong that it can withstand undermining of this kind, an undermining which in some measure reinforces the myth. ${ }^{19}$ Nevertheless, it is perhaps not a coincidence that Deneuve has been prepared to allow her "ice-maiden" image to be undermined in the same period as the new representation of women discussed here, even if, in the end, although Deneuve has the same qualities of distance and coldness as many of the actresses mentioned, she cannot approach their quotidianness. This is partly due to the narrative; the exploration of the enigma of the stolen diamonds is also an exploration of herself as enigma (the lost diamonds functioning as a metaphor for the effect of time on Deneuve's body). The explanation of the enigma of the stolen diamonds is less important than the fact that it reinstates the enigma of Deneuve by showing history repeating itself in the younger woman who, in transparent allusions to Alfred 
Hitchcock's Vertigo (1958), mirrors her character's story, suggesting that Deneuve cannot escape her own mythology. She remains, then, despite the fissures, an enigma, as stressed by many reviewers. The paradox of her body exposed and yet still a masquerade is best put by Frodon who talks of the "écart entre le corps de la comédienne et les actes de celle qu'elle joue". ${ }^{20}$

The new representation of women, then, does not perhaps stretch to the major stars. It seems to be more prevalent in younger actresses in films whose aim is to film la condition des femmes. This might suggest, indeed, that the new representation can be seen at work, but perhaps cannot be sustained, in the sense that it is not strong enough to survive the cultural habit of woman-as-enigma. Nevertheless, the interest of exploring this possible new paradigm is that it suggests that representations of women in French cinema may be breaking away from standard star glamour and spectacle, and inscribing not an ersatz regressive-70s "real", which would merely be the reverse of "glamour", but a sense of the precarity and fluidity of the female body. It may even suggest the impossibility of the representation of the woman, as reviewers suggested of both Rivette's and Besson's Joan.

\section{Theorizing the new representations}

It is not only difficult to pin down the shift in representation, it is also, and perhaps especially, difficult to name it, because of its incommensurability with the usual binaries in discussions of representation.

A useful way of talking about the absent presence at the heart of the representation of women might be Paul Virilio's term "trajective", which he describes as "the trajectory between the subject and the object". ${ }^{21}$ However, Virilio's term relates to social organization rather than representation, and carries with it the term inscribed 
within it, the trajectory. The representations which interest me here do not imply movement, but space. That space is a neutral space, in the automotive sense of "neutral", that is, a locus in which representation is abstracted from movement, while not tending to fossilization.

There are two further ways of conceptualizing this lack of "consistency" I am claiming for the figure of woman in contemporary French cinema. First, Slavoj Zizek's Lacanian investigations into the feminine masquerade; second, at the antipodes of a psychoanalytical framework, is Gilles Deleuze's topological notion of the interstice. Between these two notions lies the in-between whose indeterminate space I would like to approach. This is a space created by a vibration, as if lack had acquired both movement and consistency, but neither were possible to see directly.

First, Zizek, who takes Jacques Lacan's basic position that woman is split between acceptance of the masquerade and resistance to it through an unfathomable enigma. Zizek adds that the latter is part of the masquerade:

The allusion to some unfathomable mysterious ingredient behind the mask is constitutive of the feminine seductive masquerade: the way woman seduces and transfixes the male gaze is precisely by adopting the role of the Enigma embodied, as if her whole appearance is a lure, a veil concealing some unspeakable secret (Zizek's emphasis). ${ }^{22}$

Zizek contrasts this with the man, who is no closer, of course, to some essential subject-hood; indeed, he is considerably further from it:

In opposition to man, who simply tries to live up to his image - to give the impression that he really is what he pretends to be - woman deceives by means of deception itself; she offers the mask as mask, as false pretence, in order to provoke the search for the secret behind the mask' (Zizek's emphasis). ${ }^{23}$ 
Woman in this respect is closer to subject-hood than man, because there really is nothing behind the mask:

A man stupidly believes that, beyond his symbolic title, there is deep in himself some substantial content, some hidden treasure which makes him worthy of love; whereas a woman knows that there is nothing beneath the mask - her strategy is precisely to preserve this 'nothing' of her freedom out of reach of man's possessive love (Zizek, Indivisible, 163).

We can see how the new representation of woman investigated here in contemporary cinema might be seen as the perfect embodiment for the impossibility of constructing woman (which is how Zizek explains Lacan's provocative "woman does not exist"; Zizek, Indivisible, 165). ${ }^{24}$ The refusal of the masquerade -- what I have suggested is a willful ordinariness, or "quotidianness" -- becomes part of the masquerade itself. It is as if the woman were saying: "Not only do I refuse the glamour which would normally be part of the masquerade, but I also refuse what you might have thought lay underneath or beside it, lack of glamour. There is just lack, nothingness, and in flaunting that nothingness through its veils, I preserve my freedom.”

Zizek counter-argues that "resistance to interpellation ... is the subject" (Zizek, Indivisible, 165; his emphasis). The fact that "I" realize that there is "nothing" in a sense proves that the subject "exists". Zizek calls this refusal to identify oneself with the symbolic mandate "subjective destitution". He argues that the (as yet nonexistent) subject is interpellated; having been interpellated, and thus constituted as a subject, the subject submits to the interpellation, and thence to subjecthood, while accepting that there was never an "original" subject, thus retaining a sense of resistance which "stands in" for the being-subject: 
The anti-ideological gesture par excellence is therefore the act of 'subjective destitution' by means of which I renounce the treasure in myself and fully admit my dependence on the externality of symbolic apparatuses - fully assume the fact that my very self-experience of a subject who was already here prior to the external process of interpellation is a retroactive misrecognition brought about by that very process of interpellation (Zizek, Indivisible, 166).

Zizek's Lacanian response to this hypothetical Althusserian counter-argument is that there is nothing but an empty place, an absence or lack at the heart of what we might have wished to articulate as the subject: "nothing takes place but the place itself. The process of interpellation fills out an empty place which must already be here if this process is to take place" (Zizek, Indivisible, 167).

Zizek's clever opposition between a space of resistance which posits, or introjects the subject, and space tout court from which the subject is forever (r)ejected is, more or less exactly, beside the point for my purposes, even if his counter-argument, to which I shall return, with its emphasis on resistance might seem to tally with the resisting woman as discussed above. Whether the new representation is a "subjective destitution" from subject-hood, or confirmation of an empty place which is the condition of the impossibility of subject-hood, "woman" in this new representation is outside subject-hood, constructing not herself, but something other, which could be called the acting out of the enigma. By this I mean both of the two possible definitions of acting out: she acts out (from) the space of the enigma, and also leaves or "resigns from" the enigma in that process (rather than resigning herself to it), while still being contained within it; hence my comment above of a movement paradoxically caught in "neutral", and my attempt to suggest a movement continuously reintegrating itself within its source by the use of "(from)". 
To be theoretically acceptable, the Lacanian explanation would have to apply to all representations of woman; but is there not a difference in degree, maybe even in quality, between Rivette's Joan and Besson's Joan $?^{25}$ Zizek's argument would have to be valid for both; both would have to be the acting out (from) a place of nothingness.

The trouble (for the moment) is that both do precisely that. There is little difference between Besson's "spectacular" Joan, and Rivette's “more human” Joan. Both are inhuman, machines whose purpose is to bring into being the nothingness at the heart of the subject by transcending both gender and death, and both of whom confront, interestingly, the notion of interpellation through their "voices". (As Zizek points out, hysteria, which I am here relating to Joan's voices, is "a radically ambiguous protest against the Master's interpellation which simultaneously bears witness to the fact that the hysterical subject needs a Master, cannot do without a Master"; Zizek, Indivisible, 163-64). Surely, though, we intuit a difference between these representations?

Deleuze's notion of the interstice might help us to conceptualize the space inbetween, the space where subjecthood becomes problematic in the structure elaborated so far. It is a term Deleuze uses to identify the shift from the action-image to the timeimage. In the latter, the cut between two images both joins and separates:

La coupure, ou l'interstice entre deux séries d'images, ne fait plus partie ni de l'une ni de l'autre des séries: c'est l'équivalent d'une coupure irrationnelle, qui détermine les rapports non-commensurables entre images .... Cette imagetemps met la pensée en rapport avec un impensé, l'inévocable, l'inexplicable, l'indécidable, l'incommensurable. Le dehors ou l'envers des images ont 
remplacé le tout, en même temps que l'interstice ou la coupure ont remplacé l'association. ${ }^{26}$

More importantly, he explains how the interstice questions the image-structure which it constitutes; it is a "vide qui n'est plus une part motrice de l'image, et qu'elle franchirait pour continuer, mais ... la mise en question radicale de l'image" (Deleuze, 235). The "questioning" by the subject of what constitutes her is precisely what I have tried to explore above.

An obvious objection to the use of Deleuze's interstice is that his analyses are a topography of montage, rather than of representation. Another objection is that the interstice is irrational for Deleuze. Using it, like Zizek's notion of hysteria above, is counterproductive, however else these terms may help us to understand the new representation. The new representation is no more irrational than rational. It exists, contingently, even if it exists as slippage and evanescence.

In the final part of this argument, then, I would like to work with and out from Zizek's notion of empty space before resistance, and Deleuze's interstice. The latter at least has the advantage of suggesting not an empty unrelated space, but a space relative to what surrounds it, an in-between space, which acknowledges the inevitability of binaries while, perversely, exploring another space. It is more in tune with notions of transitions and "border-crossings" which render subjecthood -- and here one thinks back to the 1970s Deleuze of L'Anti-CEdipe - more fluid, deterritorialized.

"Interstice" is one of many terms formed on the root *sta-, meaning "to stand". Interstice thus implies a "standing between". The new representation stands between "resistance" and "enigma"; between uneroticized depth and eroticized surface; between the unspectacularized and the spectacularized. In-between these binaries is 
the interstice, where the woman would insist, if only the space in question were more consistent, less transitory, less fluid. If the space is fluid, it is because the new representation is neither one thing nor another, but both and neither, in constant flux. To take Rivette's Joan again: Bonnaire's performance oscillates between woman-asresistance-to-enigma (her "human-ness", her calculated "ordinariness"), and womanas-enigma ("what does the woman want?"). The space in question, then, is both a space in question and the space of a question; it is not the woman who insists, but the space which we intuit through the woman that insists. The woman "ex-ists", she "stands out" from the space, and in so doing allows us to glimpse Zizek's "empty space". To put it another way, which refuses woman-as-enigma, as object of erotic contemplation: the woman is not the enigma; the space is the enigma.

There is an obvious objection to this formulation: the lady vanishes, and only the space exists; as Zizek says above, "nothing takes place but the place itself". The enigmatic habit has slipped off the shoulders of the glamorous femme fatale to land on the space she inhabits, leaving behind an unglamorous body, an ordinariness, and imparting fatal attraction to the space. And yet, the increasing interest in space in film, concording with what John Urry, in another context, calls the "spectacle-ization of place", suggests that the shift is not isolated. ${ }^{27}$ The nature of that space is an issue which we cannot pursue here; but briefly, what do we desire if we no longer desire a body? Or is the new body I have tried to define in this paper just as much a lure, a body onto which we project our lack?

But the woman does exist in relation to the space. Going back to Zizek's counterargument, she exists because she resists. What matters is the way she resists. What happens in the space is not the space itself, but the space forever negotiating itself through woman and her masks. Woman and her masks are no longer the enigma; it is 
the space they constantly create and destroy as they are worn and cast off which reconstitutes itself ceaselessly as enigma. The new representation is in fact a constantly shifting plurality, new representations, in Protean transition, marked by undecidability (one of Deleuze's descriptions of the interstice).

What could we call these new representations? In deference to Deleuze, I am tempted to use the term "interstitial" woman. There are problems with the term, though, because, like Zizek's empty space, it suggests an absence, whereas the representations are there, captured fleetingly, often still trapped in the old binaries, but traversing them, fissuring them. For that reason, I would favor a neologism which combines the interstice with the transitional, and which is close to Virilio's "trajective", but deals essentially with a different space: transtitial woman. The interstice which characterizes the transtitial woman is transitional because it is the space through which the new representations transit; transitional, too, because it is a provisional formulation; we could no doubt do better than this.

Or could we? Even if we agree that women in French cinema may be being represented differently, how much of this is clear to spectators whose cultural habits incline them to woman-as-enigma? It was with this in mind that I suggested that my formulation of "uneroticized depth", which I intended to signal de-iconization, might not survive enigmatization and re-iconization as yet another version of woman-asenigma.

Part of an answer lies with the director at the heart of this special number. Several of the films discussed above have one key film in common: Agnès Varda's Sans toit ni loi (1985), whose nomadic resisting heroine, Mona, played by Bonnaire, resurfaces, as was pointed out by many reviewers, in the performances of Dequenne, Kiberlain, Régnier, and Bonnaire herself as Joan, as well as in the narratives of many of the films 
discussed here. It is, admittedly, a big leap from those fictions, where actresses act, to Varda's Les Glaneurs et la glaneuse (2000), where the director herself 'acts out' spectacularization, undermining spectacle by her insistence on filming the ravages of old age on herself. The female part-object is defetishized (Varda's hair, for example, or her hands), by being contrasted with other objects such as potatoes, or found industrial objects. She is, paradoxically, not thereby objectified, but subjectified, because she not only controls the image as director, but is also the subject of at least part of the film. La glaneuse could therefore be seen as the last in a line of figures, arguably beginning with the heroine of Cléo de 5 à 7 (1962), who are deconstructions of woman-as-enigma. But this is only part of an answer, not least because of the difference in genre (fictions vs. documentary) and age (Varda vs. young actresses) to the question of whether spectators can be as resisting as Cléo, Mona and Agnès to the lure of the fetish, however much both women and men directors have been exploring ways of reframing women's bodies. ${ }^{28}$

\footnotetext{
${ }^{1}$ Marine Landrot, "Rosetta", Télérama, 9/29/1999. This and many of the subsequent references are from the frequently unpaginated reviews collected at the $\mathrm{BiFi}$ (Paris).

2 Thierry Cheze, "Rosetta", Studio 149 (1999): 12.

${ }^{3}$ Gérard Lefort, "Rosetta, d'urgence", Libération, 5/24/99.

${ }^{4}$ Jacques Mandelbaum, "Sur les pas de Rosetta, Joconde de la fracture sociale", Le Monde, 9/29/99: 32.

5 Jean-Pierre and Luc Dardenne: "Les films appartiennent à ceux qui les regardent ", Le Monde, 9/29/99: 33.

${ }^{6}$ Notably Un héros très discret (Jacques Audiard, 1996), Beaumarchais, l'insolent (Edouard Molinaro, 1996), and Quadrille (Valérie Lemercier, 1997).

${ }^{7}$ Jeff Kline, "Benoît Jacquot's Septième ciel: Revisiting the boundaries between cinema and hypnosis", Studies in French Cinema 1 (2001): 43.

${ }^{8}$ Jean-Michel Frodon, "Souriante enquête sur un indicible secret", Le Monde, 12/18/97: 26.

${ }^{9}$ Sandrine Kiberlain/Laetitia Masson, “Les affinités électives”, Studio 154 (2000): 91.

${ }^{10}$ Les roseaux sauvages (André Téchiné, 1994), Clubbed to death (Zauberman, 1996), À toute vitesse (Gaël Morel, 1996), and J'aimerais pas crever un dimanche (Didier Le Pêcheur, 1998).
} 
${ }^{11}$ Elizabeth Gouslan, "Natacha Régnier: L’ange sans âge”, L’Evénement du jeudi, 9/17/98.

${ }^{12}$ Sandrine Bonnaire, "Jeanne d'Arc est un peu tête à claques" (interview), Télérama 2300 (1994): 32.

${ }^{13}$ Fabienne Pascaud, "Jeanne la Pucelle", Télérama 2300 (1994). "Prosaïque" is a word also used by Charles Sylvestre, the interviewer of the co-script-writer Pascal Bonitzer, in "Pascal Bonitzer: il fallait laver la figure de Jeanne", L'Humanité, 2/9/94.

${ }^{14}$ Daniel Toscan du Plantier, Jeanne éternelle", Figaro-Magazine 2/12/94.

15 Jean-Michel Frodon, "Un miracle en marche", Le Monde, 2/10/94.

${ }^{16}$ Pierre Murat, "Jeanne d'Arc", Télérama, 11/3/99.

${ }^{17}$ Didier Péron, "Jeanne dépucelée", Libération, 10/27/99.

${ }^{18}$ Luc Besson, "Une fille plongée dans l'extraordinaire", L'Express, 10/28/99.

${ }^{19}$ See Ginette Vincendeau, Stars and Stardom in French Cinema (London : Continuum, 2000): 209-10.

${ }^{20}$ Jean-Michel Frodon, "Pour tous les diamants du monde", Le Monde, 10/8/98: 34.

${ }^{21}$ Paul Virilio, Politics of the Very Worst (New York: Semiotext(e), 1999), 39-40.

${ }^{22}$ Slavoj Zizek, "Death and the Maiden", in The Zizek Reader, edited by Elizabeth Wright and Edmond Wright (Oxford: Blackwell, 1999), 214.

${ }^{23}$ Slavoj Zizek, The Indivisible Remainder: An Essay on Schelling and Related Matters (London/New York: Verso, 1996), 161.

${ }^{24}$ Lacan's provocative statement can be found in Jacques Lacan, Télévision (Paris: Seuil, 1974), 60.

${ }^{25}$ To say nothing of the difference in degree between woman in life and woman in film. To be more precise, and to question my own formulation of this argument, is it possible to have 'woman-as-mask-that-hides-the-absence-of-essence' interchangeable with 'woman-respresented-as-ordinary-in-a-fiction-film' ? (I am grateful to Mireille Rosello for pointing out this conundrum.)

${ }^{26}$ Gilles Deleuze, Cinéma 2: L'Image-temps (Paris, Minuit, 1985), 278-9.

27 "Contemporary societies are developing less on the basis of surveillance and the normalisation of individuals, and more on the basis of the democratisation of the tourist gaze and the spectacle-ization of place"; John Urry, The Tourist Gaze (London: Sage, 1990), 156.

${ }^{28}$ I am grateful to Chris Perriam for his comments on an earlier draft of this paper. 